\title{
The View from HQ
}

George M. Eberhart

Editor, C\&RL News

$C \downarrow R L$ News was born in December 1939 in the back pages of the first issue of ACRL's College and Research Libraries. At that time it was merely a column called "News from the Field," edited by Willard P. Lewis, librarian at Penn State, but it reported on acquisitions, special projects, exhibits, appointments, and deaths (including one unfortunate librarian who was aboard a ship torpedoed by a German submarine).

By 1966 the $C d R L$ news pages, which now

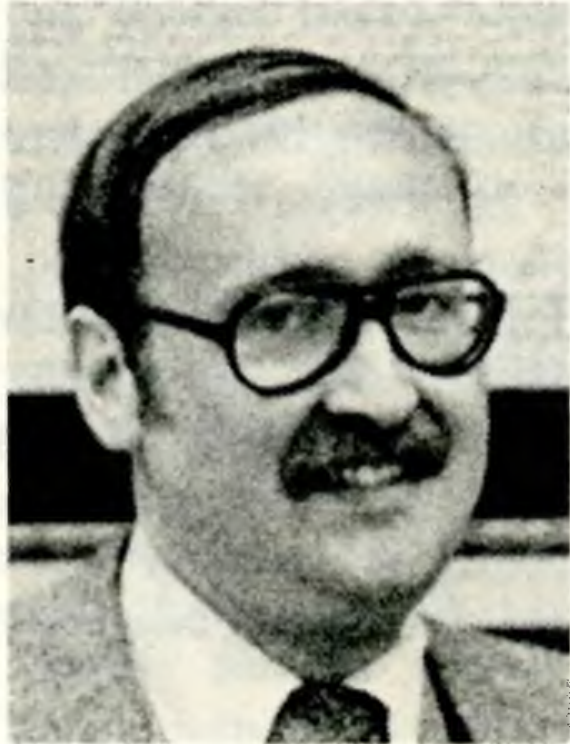

George M. Eberhart included classified ads, a calendar, library publication notices, grants, and conference news, were straining for more space. At their midwinter meeting the ACRL Board of Directors decided to accept the recommendation of the Publications Committee that the journal be split into two parts: one bimonthly journal for scholarly articles, and another monthly publication for news dissemination.

David Kaser (who is now helping to steer ACRL into the 1990s) became the first official news editor with the March 1966 issue by virtue of his position as editor of $C \mho R L$. However, it quickly became apparent that $C \downarrow R L$ News was a substantial publication in its own right and required the full attention of a separate editor. David Doerrer, then at Cornell, was appointed volunteer news editor to assist Kaser beginning with the September 1968 issue.

Ten years later both the Library of Congress and the U.S. Postal Service decided that $C \downarrow R L$ News was an independent publication requiring its own ISSN number and mailing permit. This prompted a major reappraisal of the magazine by the ACRL Board in 1979. In order to have more control over the timeliness of CむRL News, the Board appointed the first headquarters staff editor, Jeffrey Schwedes.

Additional benefits soon became obvious. An in-house editor can devote more time to the details of news gathering, editing, production and advertising, and the central location at headquarters in Chicago gives the editor immediate access to news of all ACRL activities. This allows for more timely, efficient, thorough and diversified news coverage, as well as close attention to classified advertisers and improvements in content and design.

That, basically, is why I am here and what I have been doing for the past twenty months.

The $C \triangleleft R L$ News editorial board, established in 1980 , provides me with welcome advice and recommendations on the content of the magazine. We meet twice a year at ALA conferences to discuss plans and ideas for future issues. The New Technology column, which was launched last month, is the result of a suggestion by an editorial board member.

Daily activities at the C\&RL News office depend entirely on the magazine's production cycle. Throughout any given month I review all the articles, columns and news items submitted to me to determine their suitability for publication. Countless press releases and library newsletters also must be examined closely for relevant information. The ACRL headquarters staff keeps me alerted to activities of sections, committees and chapters, and some members call in with tips on events they are involved with. By the 21 st of each month, I usually have a very good idea of the contents of the issue that will appear five weeks later.

At this point manuscript copy is typed, proofed, marked, and otherwise prepared for the typesetter, who needs about ten days to set it into galleys. Attention then shifts to the classified advertising, since the deadline is the second of each month. Again, copy is typed using the ACRL word processor, marked for typesetting, and delivered to the typesetter on the 3rd after all the last-minute ads have been received. Most of the details of this immense task are handled by Judith Franklin, the CひRL News administrative secretary who also prepares the camera-ready Late Job Notices and the monthly Fast Job Listing Service.

All the galleys are returned usually by the 8 th of the month. Then the time arrives (which I affectionately call the Day of Chaos) in which the galleys must be corrected and everything fitted and scotch-taped onto a dummy in the way I wish it to appear in final form. Copy does not always fit neatly into the space ideally postulated for it, so at this stage there may be numerous eleventh hour editorial changes. The more timely the news, the better, so I always attempt to get this back to the typesetter in 24 hours.

In another week or so the final boards, camera-ready copy (such as the Late Ads and the Washington Hotline), photographs, and display ads are all sent to our printer in Missouri. The magazine is mailed at the end of the month, and by this time the cycle has already begun for the 
next issue.

An effort is now underway to shorten the turnaround time by a week or more and reduce costs in the long run. With the proper software and modem interface, I can type all the CઐRL News copy on the ACRL word processor, insert special marks for typeface and spacing, then teletransmit the full text to the typesetter by phone line. This is the next best thing to having our own in-house composition equipment, because keyboarding is the most time-consuming and costliest stage in typesetting. At least some of the June issue will be produced this way, and all of the issues following.

To keep myself up-to-date I occasionally attend workshops on different aspects of magazine publishing. Most helpful have been those sponsored by Folio magazine in New York. Last year I participated in workshops on direct mail subscription promotion, selling advertising in association magazines, production cost cutting, editing skills, and cover design-all of which have proven very useful to the C\&RL News design and budget.
My other responsibilities in ACRL beyond C\&RL News management include supervising the Jobline, which is a recorded telephone message describing professional librarian positions currently open and which is changed weekly. I also write press releases for ACRL and in general advise the association in matters of editing, publishing, and public relations.

Several times during the year I compose and mail surveys on various topics to pre-selected non-ARL academic libraries. The results of the most recent survey on library photocopying appeared in the April issue, and another survey on advertising library positions is underway.

As always, I welcome articles, news items, or ideas for publication in $C \& R L$ News. Guidelines for submission of manuscripts appeared in the March issue, pp.85-86. Quite often I get many ideas by talking to members at annual conference, so if you want to ask questions, share viewpoints or news, or just chat amiably, feel free to contact me in Philadelphia.

\section{Continuing Education}

\section{$\mathrm{CE}$ at the University of California, Berkeley}

Reference librarians working in separate units of large institutions such as the University of California, Berkeley, can often find themselves feeling somewhat isolated. Yet they are in fact often faced with the same problems and questions as their colleagues in other units.

In an effort to provide reference librarians with an opportunity to share their concerns and ideas and at the same time to try to seek some solutions, the library's Reference Services Committee developed a series of reference forums. These forums are held on a variety of topics and are designed to have a maximum of thirty-five participants to make discussion easier. The committee has urged representatives of many different units within the library system to attend. At each forum, which is scheduled as a two-hour informal bag lunch, there are panelists who provide an introduction and serve as moderators for the discussion.

The topic of the first forum, which was held in the Fall 1981 quarter, was "Reference Priorities." Three panelists provided the basis for discussion by distributing three case studies, entitled "Take a Number?," which illustrated a number of typical situations faced by librarians at a busy refer- ence desk. The discussion opened with a summary of those factors which affect the selection of priorities at the desk: for example, how many patrons are waiting, their attitudes, their status, and the level of difficulty of their questions.

The first case study presented the problem of how to maintain a reasonable balance when, at the same time as a long-distance phone request, a foreign student who has difficulty with English has asked what is apparently a complex question, and at the end of a long line the chancellor's son might be waiting. Several solutions were proposed, such as first ascertaining if in fact the phone request is a simple matter before automatically putting the patron on hold. If it is obvıously a time-consuming question, there is justification for asking the patron to phone back at a suggested time or offering to return the call later.

It was generally agreed that patrons waiting at the desk should be taken in order; however, the librarian should acknowledge in some manner an awareness of the others. The importance of body language was discussed. The status of the patron as a rule should not affect the order in which questions are answered, although it is possible to suggest to faculty members that they might wish 